\title{
Insulin Resistant Diabetes Mellitus with Acanthosis Nigricans and Hyperandrogenism
}

National Cancer Institute

\section{Source}

National Cancer Institute. Insulin Resistant Diabetes Mellitus with Acanthosis Nigricans and Hyperandrogenism. NCI Thesaurus. Code C131836.

A syndrome of insulin resistance caused by mutation(s) in the INSR gene, encoding the insulin receptor. This condition is characterized by a clinical triad of hyperinsulinemia, acanthosis nigricans, and hyperandrogenism without lipodystrophy. This is the least severe of a spectrum of disorders; the other two conditions are Rabson-Mendenhall Syndrome and Donohoe Syndrome. 